\title{
Vaginal Leiomyoma
}

National Cancer Institute

\section{Source}

National Cancer Institute. Vaginal Leiomyoma. NCI Thesaurus. Code C6373.

A benign smooth muscle neoplasm arising from the vagina. It is characterized by the presence of spindle cells with cigar-shaped nuclei, interlacing fascicles, and a whorled pattern. 